\title{
An Experimental Study of Greenhouse Gas Concentration on the Maximum Power Point of Solar PV Panels
}

\author{
Bhabani Patnaik \\ School of Electrical Engineering \\ KIIT Deemed to be University \\ Bhubaneswar, India \\ bhabani.twinkle@gmail.com
}

\author{
Sarat Chandra Swain \\ School of Electrical Engineering \\ KIIT Deemed to be University \\ Bhubaneswar, India \\ scs_132@rediffmail.com
}

\author{
Ullash Kumar Rout \\ Department of Electrical Engineering \\ College of Engineering and Technology, \\ Bhubaneswar, India \\ ullashrout@rediffmail.com
}

\begin{abstract}
The energy demand increases along with demographic and development growth. India is the second-most populous country in the world and most of its population needs more energy as its human and energy development indices are rather low. So, the country depends on cheaper sources of energy which have ample effects on the environment. Many energy sources are polluting, but solar energy is pollution-free and its availability is abundant with zero cost. Solar Photo Voltaic (PV) technology is the best technology to harness electricity. The effect of varying environmental factors regulates the performance factors of this technology. Its efficiency mainly depends on the concentration of greenhouse gases (GHGs), ambient temperature, module temperature, incoming solar radiation intensity, and PV material composition. To understand the behavior of solar panels on maximum power point under various GHGs concentrations, three experiments were conducted. One in normal atmospheric $\mathrm{CO}_{2}$ concentration and two in higher $\mathrm{CO}_{2}$ concentration chambers.
\end{abstract}

\section{Keywords-solar PV; GHGs; CO2 concentration; OTC; MPP}

\section{INTRODUCTION}

As of $2019,35 \%$ of India's installed electric generation is from renewable sources [1], which is globally the largest producer percentage. Even though India is committed by the Paris agreement that by $2030,40 \%$ of its total electric energy will be generated from non-fossil fuels, it targets to achieve $57 \%$ by 2027 . Until the end of 2019 , India's total renewable energy capacity was $130.68 \mathrm{GW}$ which is $35.7 \%$ of its total electricity generation [2]. The government of India has focused on solar PV systems due to their reliable and cost-effective nature [3]. Especially in India, the climatic conditions are suitable for this technology because it needs higher solar irradiation as input to acquire better output at standard test conditions [4]. Nowadays, different types of solar PV modules are used (polycrystalline, monocrystalline, etc.) [5]. The output of a solar PV depends on various factors like Greenhouse Gases (GHGs), module material, panel area, cable thickness, climatic conditions (humidity, temperature), etc. [6]. Due to the growing population and the climate change, GHGs also increase vigorously. GHGs include $\mathrm{CO}_{2}, \mathrm{CH}_{4}, \mathrm{NO}_{2}, \mathrm{SF}_{6}, \mathrm{O}_{3}$, perfluorocarbons (PFCs), water vapors, etc. Out of all these gases, $\mathrm{CH}_{4}$ and $\mathrm{CO}_{2}$ have the highest effect due to their higher concentrations in the atmosphere (16\% and $65 \%$ respectively). It can be concluded that it is necessary to produce more green electricity as the climatic changes [7].

\section{THE CONCENTRATION OF $\mathrm{CO}_{2}$ IN THE ATMOSPHERE}

The concentration of $\mathrm{CO}_{2}$ in the atmosphere ranges from 380 to $420 \mathrm{ppm}$, to an average of $400 \mathrm{ppm}$. It has been shown that the polluting gases from fossil fuels and industry will grow by $3.2 \%$ by 2020 . The burning of fossil fuels such as coal, petroleum products, and natural gas produces $\mathrm{CO}_{2}$. It is observed that the rate of growth is increasing day by day due to the heavy demand for energy production and transportation [8]. In this paper, a higher concentration of $\mathrm{CO}_{2}$ was taken to analyze the performance of solar PV panels under these climatic conditions because as the $\mathrm{CO}_{2}$ concentration increases, so is the demand of renewable energy (i.e. especially solar PV technology). From Figure 1, we can see the rate of growth of $\mathrm{CO}_{2}$ in every 10 years.

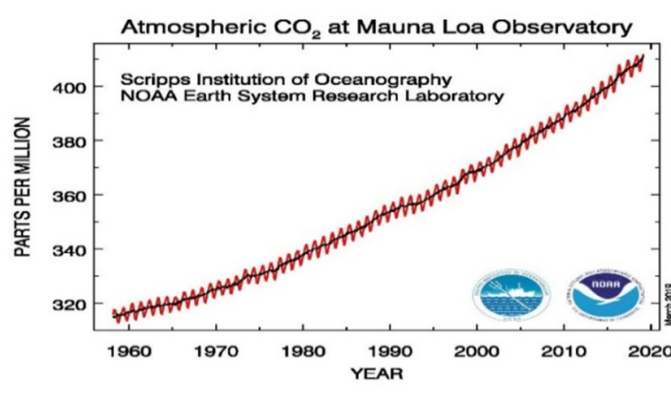

Fig. 1. The increasing rate of $\mathrm{CO}_{2}$ concentration.

\section{EXPERIMENTAL ANALYSIS}

An experimental analysis has conducted in the National Rice Research Institute, Cuttack. They had built special chambers, known as Open Top Chambers (OTCs) [9], where the concentration of $\mathrm{CO}_{2}$ is kept higher than its atmospheric concentration (400ppm).Two OTCs were made with two 
different concentrations of $\mathrm{CO}_{2}, 550 \mathrm{ppm}$ and $575 \mathrm{ppm}$ respectively. The experiment was carried out for three days (10 A.M. to 4 P.M.) in dry season (oct-15-2019 to oct-17-2019). The OTCs were used for conducting the $\mathrm{CO}_{2}$ enrichment experiment. They were arranged in the field with a block design which is rectangular in shape $(6 \mathrm{~m} \times 4 \mathrm{~m} \times 3 \mathrm{~m})$. These chambers are made up of transparent polycarbonate sheets with about 80 to $90 \%$ transparency. The upper part of the OTC is open. The temperature for all the chambers was recorded with a digital thermometer. Pure $\mathrm{CO}_{2}$ gas was blown $\left(2.5 \mathrm{~kg} / \mathrm{cm}^{2}\right)$ inside the OTCs through perforated polyvinyl tubes regulated by solenoid valves. The $\mathrm{CO}_{2}$ data logging, sampling and the concentration of each $\mathrm{CO}_{2}$ on each OTC were performed by a personal computer (PC) through an automatic digital meter and a microcontroller. Figures 2-3 show the design of open-top chambers and the system where the $\mathrm{CO}_{2}$ concentration, temperature and humidity were recorded.

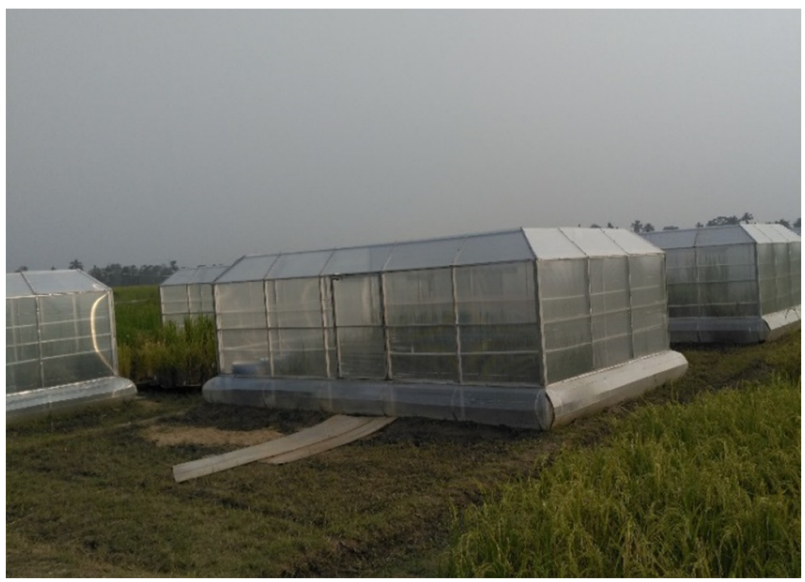

Fig. 2. OTCs with different $\mathrm{CO}_{2}$ concentrations.

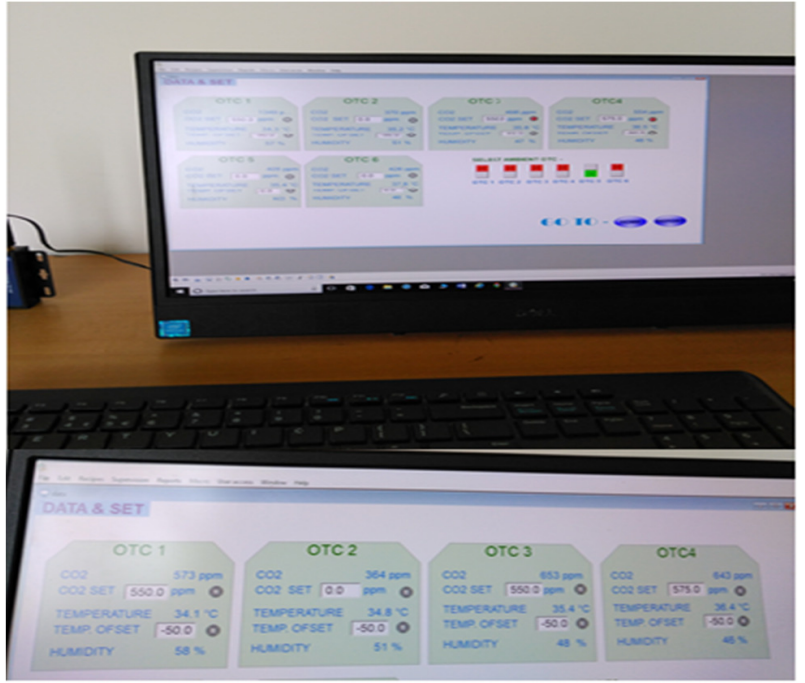

Fig. 3. The recording system.

In order to evaluate the performance of the solar PV panels under higher $\mathrm{CO}_{2}$ concentrations, three $20 \mathrm{~W}$ PV modules were kept in three different OTCs. The experimental set-up of each chamber is given in Figures 4-6. Each module was kept in its respective chamber and the measuring instruments were kept outside, so that the effect of $\mathrm{CO}_{2}$ on the solar PV panel could be properly analyzed.

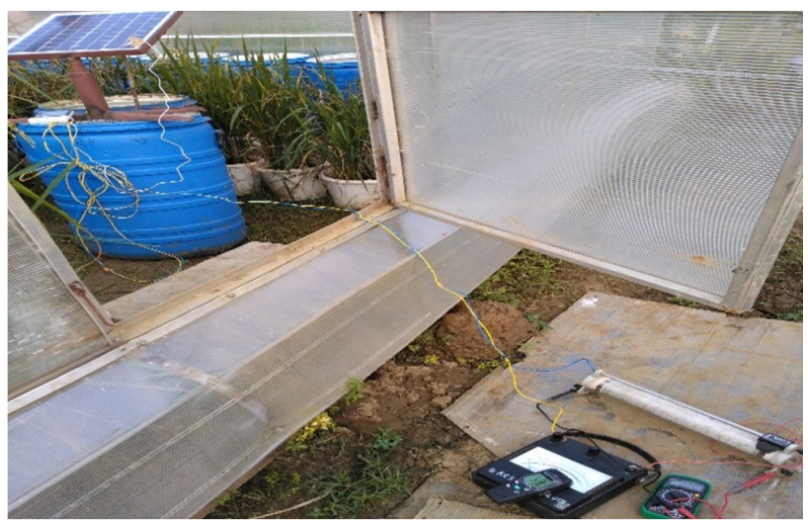

Fig. 4. Solar PV Panel under OTC 1 with $575 p \mathrm{pm} \mathrm{CO}_{2}$ concentration.

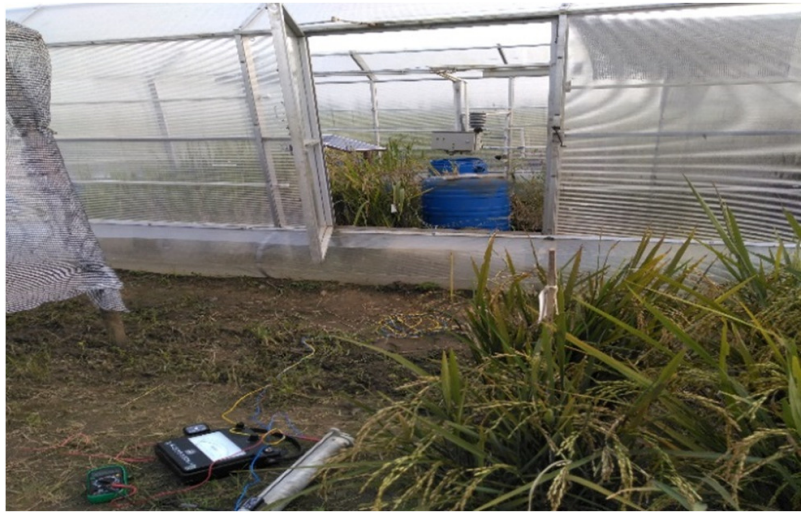

Fig. 5. Solar PV panel in OTC 4 with 550ppm $\mathrm{CO}_{2}$ concentration.

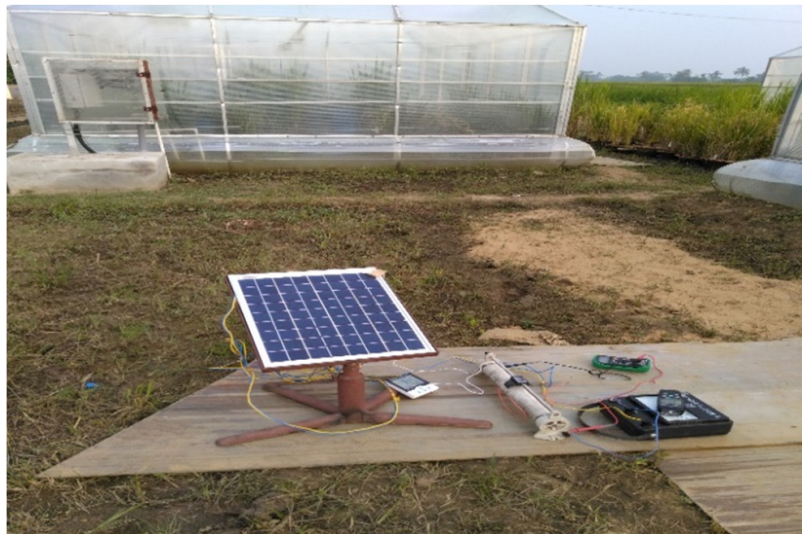

Fig. 6. Solar PV panel on atmospheric $\mathrm{CO}_{2}$ concentration of $400 \mathrm{ppm}$.

The solar PV module description and the required instruments for the experiment are given in tabular form in Table I. The experiment was conducted in order to acquire knowledge of the effect of higher concentrations of $\mathrm{CO}_{2}$ on the performance of a solar PV module. The experimental analysis has continued for three days and the data were properly 
synthesized and analyzed. In this paper, the data of only a single data are shown, representing the best outcome from the three-day experiment.

TABLE I. REQUIRED INSTRUMENTS FOR THE EXPERIMENT

\begin{tabular}{|c|c|c|}
\hline Instruments required & Range & Unit \\
\hline Solar panel & $20 \mathrm{~W}$ & 3 \\
\hline Ampmeter & $0-1 \mathrm{~A}(\mathrm{DC})$ & 3 \\
\hline Voltmeter (multimeter) & $0-100 \mathrm{~V}(\mathrm{DC})$ & 3 \\
\hline Rheostat & $0-145 \Omega$ & 3 \\
\hline Solar meter & Measuring irradiation & 1 \\
\hline Solar PV stand & Tilt angle-22deg. & 3 \\
\hline Thermometer & $0-500^{\circ} \mathrm{C}$. & 3 \\
\hline
\end{tabular}

TABLE II. SOLAR PV MODULE SPECIFICATIONS

\begin{tabular}{|c|c|}
\hline Parameter & Specification \\
\hline Maximum power & $20 \mathrm{~W}$ \\
\hline Maximum voltage & $18.25 \mathrm{~V}$ \\
\hline Maximum current & $1.10 \mathrm{~A}$ \\
\hline Open circuit voltage & $21.96 \mathrm{~V}$ \\
\hline Short circuit current & $1.17 \mathrm{~A}$ \\
\hline Cell technology & Polycrystalline \\
\hline Dimension $(\mathbf{m m})$ & $(356 \times 490 \times 20)$ \\
\hline
\end{tabular}

\section{RESULTS}

All the data were taken simultaneously for the three systems on a sunny day. Voltage, current, ambient temperature, and module temperature of all setups were taken each hour from 10 AM to 4 PM. The Maximum Power Point (MPP) was traced from these data.

In Figure 7 , the data were taken at $10 \mathrm{AM}$ when the irradiation was $715 \mathrm{~W} / \mathrm{m}^{2}$, in Figure 8 , at $11 \mathrm{AM}$ when the irradiation was $850 \mathrm{~W} / \mathrm{m}^{2}$, in Figure 9, at noon when the irradiation was $915 \mathrm{~W} / \mathrm{m}^{2}$, in Figure 10 , the data were taken at 1 $\mathrm{PM}$ when the irradiation was $750 \mathrm{~W} / \mathrm{m}^{2}$, in Figure 11 , the data were taken at $2 \mathrm{PM}$ when the irradiation was $660 \mathrm{w} / \mathrm{m}^{2}$, in Figure 12 at $3 \mathrm{PM}$ with $550 \mathrm{~W} / \mathrm{m}^{2}$ irradiation, and in Figure 13 at $4 \mathrm{PM}$ when the irradiation was $400 \mathrm{~W} / \mathrm{m}^{2}$.

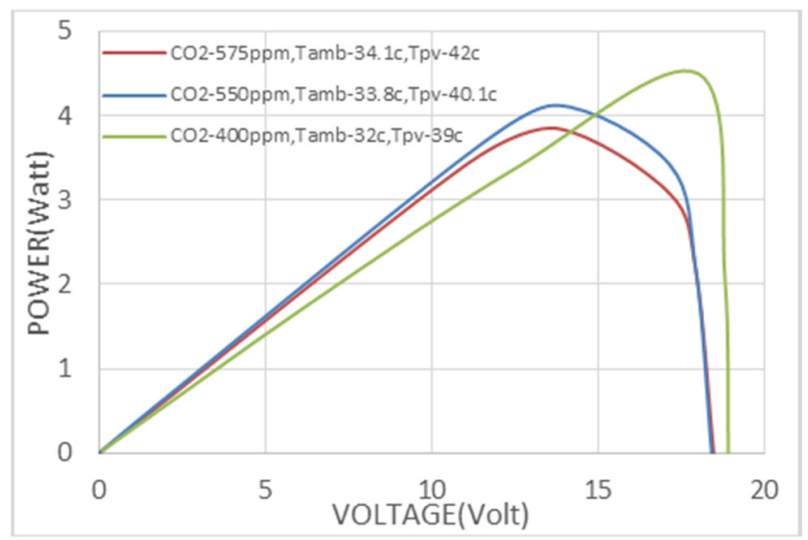

Fig. 7. PV characteristics at $10 \mathrm{AM}$.

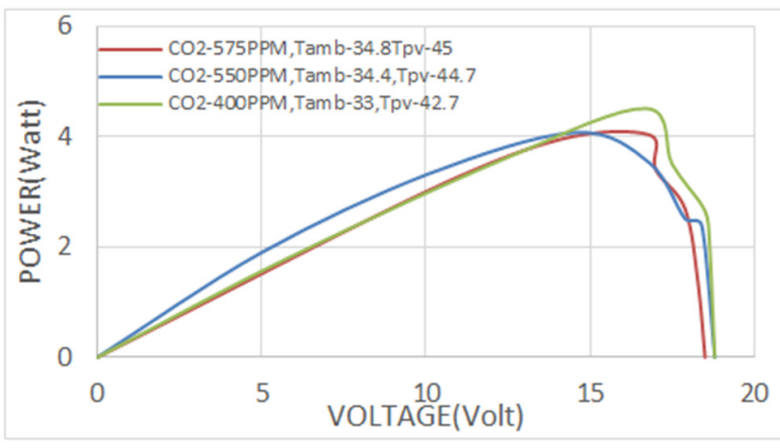

Fig. 8. Solar PV characteristics at 11 AM.

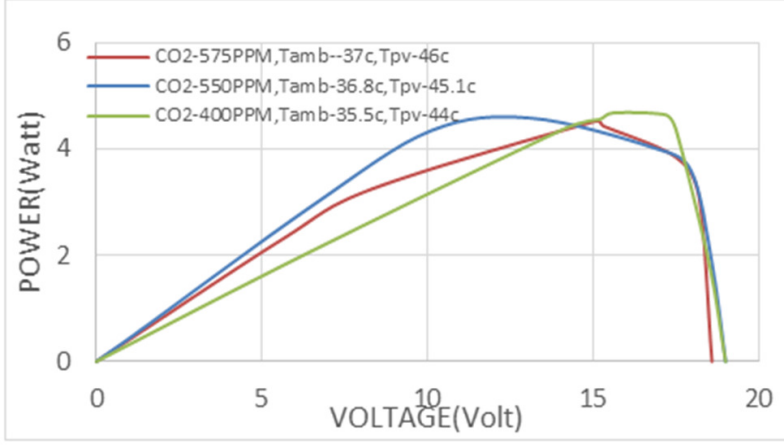

Fig. 9. Solar PV characteristics at $12 \mathrm{AM}$.

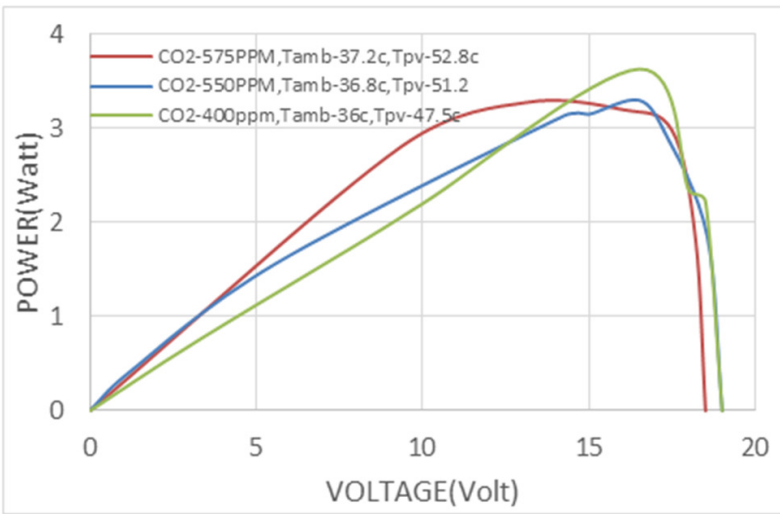

Fig. 10. Solar PV characteristics at 1 PM.

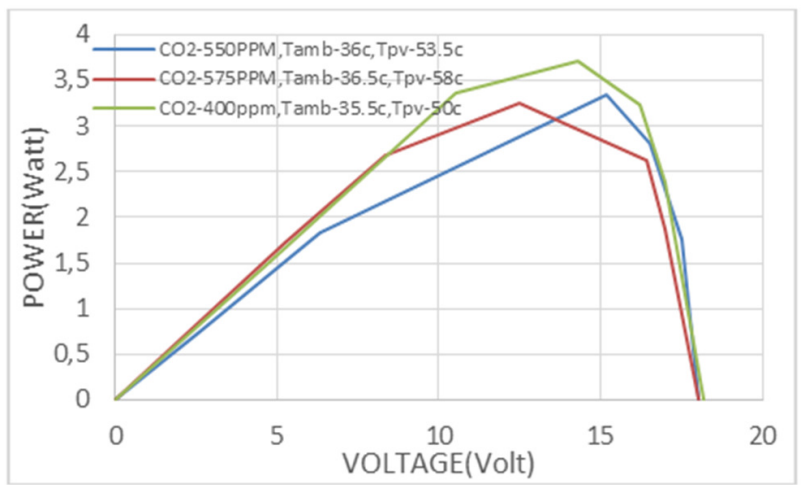

Fig. 11. Solar PV characteristics at 2 PM. 


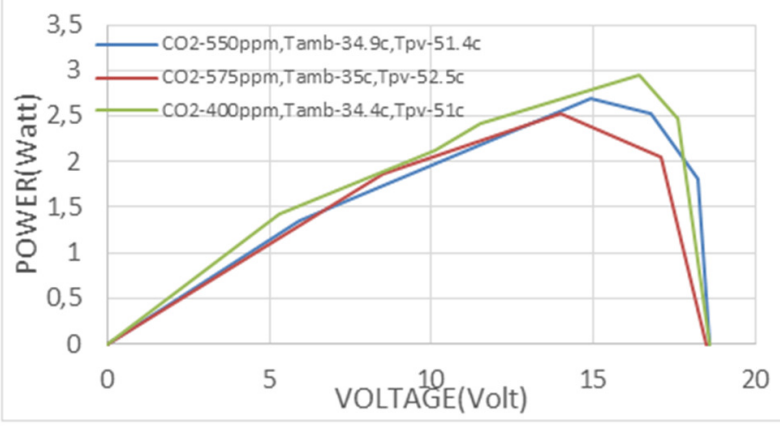

Fig. 12. Solar PV characteristics at $3 \mathrm{PM}$

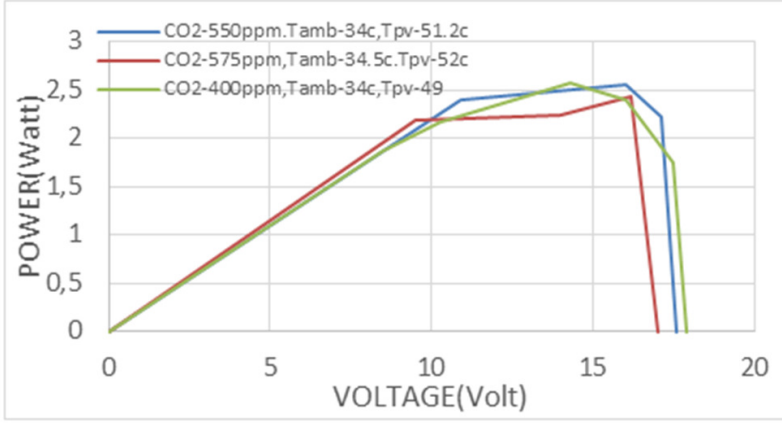

Fig. 13. Solar PV characteristics at $4 \mathrm{PM}$.

\section{DISCUSSION}

We can verify from the graphs that as the irradiation increases, the temperature of the panel also increases but at the same time, the increase of $\mathrm{CO}_{2}$ concentration has a major effect on the temperature of the solar panel. At $10 \mathrm{AM}$, the maximum power of the solar panel at $575 \mathrm{ppm} \mathrm{CO}_{2}$ was $3.85 \mathrm{~W}$, at $550 \mathrm{ppm}$ it was $4.125 \mathrm{~W}$, and at $400 \mathrm{ppm}$ it was $4.5 \mathrm{~W}$. Similarly, at $11 \mathrm{AM}$ the maximum power of the solar panel at $575 \mathrm{ppm}$ was $4.03 \mathrm{~W}$, at $550 \mathrm{ppm}$ was $4.074 \mathrm{~W}$ whereas at $400 \mathrm{ppm}$ it was $4.509 \mathrm{~W}$. We can see that when the panels were under the highest radiation (noon time), the maximum power of solar panel at $575 \mathrm{ppm}$ was $4.53 \mathrm{~W}$, at $550 \mathrm{ppm}$ was $4.585 \mathrm{~W}$ whereas at $400 \mathrm{ppm}$ it was $4.816 \mathrm{~W}$. Similarly, we can observe at every hour of that day the output maximum power or MPP of the solar PV module at 550ppm is less than the MPP of the PV module at 400ppm (ambient). And the module which is kept at $575 \mathrm{ppm}$ gives less MPP than the module kept at 550ppm. It should be noted that the same irradiance is absorbed by all the panels and that the data were taken simultaneously. Due to the higher $\mathrm{CO}_{2}$ concentration, the ambient temperature of 550ppm and $575 \mathrm{ppm}$ OTCs was higher than the ambient temperature of the panel with $400 \mathrm{ppm} \mathrm{CO}_{2}$ concentration. Due to the increase in the ambient temperature of the OTCs, the solar PV module temperature increased, which effected the MPP of the panel as shown in Figures 7-13. A small increase of the ambient temperature affects disproportionately the panel temperature and thus the maximum power of the solar PV panel is gradually decreasing.

\section{CONCLUSION}

In 2000, the concentration of $\mathrm{CO}_{2}$ in the atmosphere was $366 \mathrm{ppm}$, and now (2020) the concentration of $\mathrm{CO}_{2}$ is 400 to 405ppm. Meanwhile, the demand for solar PV energy is increasing dramatically. Research in many aspects is conducted to get maximum efficiency from the solar PV panels. There are many factors present in the atmosphere by that affect the efficiency of solar PV panels. From this experimental analysis it was observed that due to the higher concentration of $\mathrm{CO}_{2}$, the ambient temperature increases, and a small increase in ambient temperature has many effects on the panel efficiency. The temperature is inversely proportional to the module output power. So at standard test conditions, the solar panel gives maximum efficiency where the temperature should be $25^{\circ} \mathrm{C}$. Thus it is necessary to maintain the module temperature at $25^{\circ}$ $30^{\circ} \mathrm{C}$ in order to have better efficiency and performance with higher solar irradiance.

\section{ACKNOWLEDGEMENT}

The authors like to thank the National Rice Research Institute, Cuttack, Odisha for providing the necessary set-up for the experiments.

\section{REFERENCES}

[1] T. V. Krishna, M. K. Maharana, and C. K. Panigrahi, "Integrated Design and Control of Renewable Energy Sources for Energy Management," Engineering, Technology \& Applied Science Research, vol. 10, no. 3, pp. 5857-5863, Jun. 2020.

[2] A. S. Saidi, M. B. Slimene, and M. A. Khlifi, "Transient Stability Analysis of Photovoltaic System with Experimental Shading Effects," Engineering, Technology \& Applied Science Research, vol. 8, no. 6, pp. 3592-3597, Dec. 2018.

[3] A. Gholami, A. Saboonchi, and A. A. Alemrajabi, "Experimental study of factors affecting dust accumulation and their effects on the transmission coefficient of glass for solar applications," Renewable Energy, vol. 112, pp. 466-473, Nov. 2017, doi: 10.1016/j.renene.2017.05.050.

[4] K. V. Vidyanandan, "An Overview of Factors Affecting the Performance of Solar PV Systems," Energy Scan (A house journal of Corporate Planning, NTPC Ltd.), vol. 27, pp. 2-8, Feb. 2017.

[5] B. Patnaik, S. C. Swain, and U. K. Rout, "Effect of Colour Spectrum and Plastic on the Performance of PV Solar System," International Journal of Recent Technology and Engineering, vol. 8, no. 4, pp. 10843-10846, Nov. 2019, doi: 10.35940/ijrte.D4373.118419.

[6] B. Patnaik, S. C. Swain, and U. K. Rout, "Modelling and Performance of Solar PV Panel with Different Parameters," in Applications of Robotics in Industry Using Advanced Mechanisms, Cham, 2020, pp. 250-259, doi: 10.1007/978-3-030-30271-9_23.

[7] H. Wang, B. W. Ang, and B. Su, "A Multi-region Structural Decomposition Analysis of Global CO2 Emission Intensity," Ecological Economics, vol. 142, pp. 163-176, Dec. 2017, doi: 10.1016/j.ecolecon.2017.06.023.

[8] R. Heede, "Tracing anthropogenic carbon dioxide and methane emissions to fossil fuel and cement producers, 1854-2010," Climatic Change, vol. 122 , no. 1 , pp. 229-241, Jan. 2014, doi: 10.1007/s10584013-0986-y.

[9] A. Kumar, A. K. Nayak, R. P. Sah, P. Sanghamitra, and B. S. Das, "Effects of elevated $\mathrm{CO} 2$ concentration on water productivity and antioxidant enzyme activities of rice (Oryza sativa L.) under water deficit stress," Field Crops Research, vol. 212, pp. 61-72, Oct. 2017, doi: $10.1016 /$ j.fcr.2017.06.020. 